\title{
Clinical burden of severe respiratory syncytial virus infection during the first 2 years of life in children born between 2000 and 2011 in Scotland
}

\author{
Richard Thwaites $^{1} \cdot$ Scot Buchan $^{2} \cdot$ John Fullarton $^{2} \cdot$ Carole Morris $^{3} \cdot$ ElizaBeth Grubb $^{4} \cdot$ Barry Rodgers-Gray $^{2}$ (D) \\ Jonathan Coutts ${ }^{5}$
}

Received: 30 August 2019 / Revised: 30 August 2019 / Accepted: 26 December 2019 / Published online: 7 January 2020

(C) The Author(s) 2020

\begin{abstract}
National data from Scotland (all births from 2000 to 2011) were used to estimate the burden associated with respiratory syncytial virus hospitalisation (RSVH) during the first 2 years of life. RSVHs were identified using the International Classification of Diseases 10th Revision codes. Of 623,770 children, 13,362 (2.1\%) had $\geq 1$ RSVH by 2 years, with the overall rate being $27.2 / 1000(16,946$ total RSVHs). Median age at first RSVH was 137 days (interquartile range [IQR] 62-264), with $84.3 \%$ of admissions occurring by 1 year. Median length of stay was 2 (IQR 1-4) days and intensive care unit (ICU) admission was required by $4.3 \%$ (727) for a median 5 (IQR 2-8) days. RSVHs accounted for $6.9 \%(5089 / 73,525)$ of ICU bed days and 6.2\% $(64,395 / 1,033,121)$ of overall bed days $(5370 /$ year). RSVHs represented $8.5 \%(14,243 / 168,205)$ of all admissions between October and March and 14.2\% (8470/59,535) between December and January. RSVH incidence ranged from 1.7 to $2.5 \%$ year over the study period. Preterms (RSVH incidence 5.2\%), and those with congenital heart disease (10.5\%), congenital lung disease (11.2\%), Down syndrome (14.8\%), cerebral palsy (15.5\%), cystic fibrosis (12.6\%), and neuromuscular disorders (17.0\%) were at increased risk of RSVH.

Conclusions: RSV causes a substantial burden on Scottish paediatric services during the winter months.

What is known:

- Respiratory syncytial virus (RSV) is a leading cause of childhood hospitalisation.

What is new:

- This 12-year study is the first to estimate the burden of RSV hospitalisation (RSVH) in Scotland and included all live births from 2000-2011 and followed $>600,000$ children until 2 years old.

- The overall RSVH rate was 27.2/1,000 children, with 2.1\% being hospitalised $\geq 1$ times; RSVHs accounted for $6.2 \%$ of all inpatient bed days, which rose to $14.2 \%$ during the peak months of the RSV season (December-January), equating to over 1,400 hospitalisations and nearly 5,500 bed days each year.
\end{abstract}

\section{Communicated by Nicole Ritz}

Richard Thwaites

richard.thwaites@porthosp.nhs.uk

Scot Buchan

Scot.Buchan@strategen.co.uk

John Fullarton

John.Fullarton@strategen.co.uk

Carole Morris

carolemorris@nhs.net

ElizaBeth Grubb

elizabeth.grubb@abbvie.com

Barry Rodgers-Gray

Barry.Rodgers-Gray@strategen.co.uk
Jonathan Coutts

Jonathan.Coutts@ggc.scot.nhs.uk

1 Portsmouth Hospitals NHS Trust, Queen Alexandra Hospital, Portsmouth PO6 3LY, UK

2 Strategen Limited, Basingstoke, UK

3 Information Services Division Scotland, Farr Institute Scotland, Edinburgh, UK

4 Health Economics \& Outcomes Research, AbbVie Inc, North Chicago, IL, USA

5 Royal Hospital for Children, Glasgow, UK 
Keywords Respiratory syncytial virus $(\mathrm{RSV}) \cdot$ Lower respiratory tract infection $(\mathrm{LRTI}) \cdot \mathrm{RSV}$ hospitalisation $\cdot$ Bronchiolitis

$\begin{array}{ll}\text { Abbreviations } \\ \text { BPD } & \text { Bronchopulmonary dysplasia } \\ \text { CHD } & \text { Congenital heart disease } \\ \text { CLD } & \text { Congenital lung disease } \\ \text { ICD 10 } & \begin{array}{l}\text { International Classification of Diseases } 10 \text { th } \\ \text { Revision }\end{array} \\ \text { ICU } & \text { Intensive care unit } \\ \text { IQR } & \text { Interquartile range } \\ \text { ISD } & \text { Information Services Division } \\ \text { LOS } & \text { Length of stay } \\ \text { LRTI } & \text { Lower respiratory tract infection } \\ \text { NHS } & \text { National Health Service } \\ \text { PH } & \text { Pulmonary hypertension } \\ \text { RSV } & \text { Respiratory syncytial virus } \\ \text { RSVH } & \text { Respiratory syncytial virus hospitalisation } \\ \text { SD } & \text { Standard deviation } \\ \text { SIMD } & \text { Scottish Index of Multiple Deprivation } \\ \text { wGA } & \text { Weeks' gestational age }\end{array}$

\section{Introduction}

Respiratory syncytial virus (RSV) is a major cause of lower respiratory tract infections (LRTI) in early childhood, resulting in a substantial burden on health care services, particularly during the colder months (typically October-March) in Northern Hemisphere countries [1-5]. Robust epidemiological data on RSV LRTI aids planning, guides preventive strategies and helps manage healthcare resources effectively. Quantifying the burden of RSV LRTI at a national level can be difficult, due to the limited availability of suitable data sources and a lack of routine testing and confirmatory diagnoses of RSV. Study methodologies have included utilisation of databases of hospital records or medical insurance $[3,4]$ or modelling hospital admissions with national surveillance data [5]. Studies from England have reported RSV hospitalisation (RSVH) rates of $2.4-3.5 \%$ in children $<1$ year [5, 6], rising to $14.3 \%$ in those born $<32$ weeks' gestational age [wGA] [7]. To our knowledge, no studies reporting such data from Scotland have been published.

The Information Services Division (ISD) Scotland collates comprehensive national datasets covering all aspects of hospital care within National Health Service (NHS) Scotland, providing 'linked' data on the total population ( $>5$ million people) [8]. The aim of this study was to evaluate the hospital burden associated with RSV during the first 2 years of life in children born within NHS Scotland from 2000 to 2011.

\section{Materials and methods}

\section{Study population}

Data on all live births were extracted from the ISD Scottish Maternity and Birth Record dataset (SMR02) for the period 2000-2011 and each child was followed for 2 years. Those who died during the study period for any reason other than RSV-related infection, those whose records were unable to be linked between datasets (SMR02, Scottish Birth Record [SBR], General/Acute Inpatient and Day Case Record [SMR01], and Outpatient Attendance Record [SMR00]), or those who moved away from Scotland were excluded.

\section{Demographic factors}

The following demographic factors were assessed: sex, gestational age at birth, birthweight, 5-min Apgar score, need for emergency caesarean, multiple births, mother's age when giving birth, mother's smoking history at pre-delivery assessment (self-declared) and previous pregnancies. Socio-economic status was determined using the Scottish Index of Multiple Deprivation (SIMD) based on the postcode (ZIP code) of the mother, where $1=$ most deprived and $5=$ least deprived [9].

\section{Identification of RSVHs}

RSVHs were defined and analysed as having one of the following three International Classification of Diseases 10th Revision (ICD-10) codes: J12.1 (RSV pneumonia); J20.5 (acute bronchitis due to RSV); or J21.0 (acute bronchiolitis due to RSV) (defined as 'definite' RSV; Table 1). Whilst RSV testing is routinely undertaken in virtually all paediatric inpatient units in Scotland, to provide an estimate of the maximal impact of RSVH, additional ICD-10 codes were analysed covering 'probable' and 'possible' RSVHs. The likelihood of the 'probable' and 'possible' groups being true RSV diagnoses was analysed in two ways. Firstly, these groups were compared to the 'definite' group in terms of seasonality. Secondly, any hospitalisations that occurred out of the RSV season in the 'probable' and 'possible' groups, above the rate in the 'definite' group, were reflected across the whole year and assumed not to be true RSVHs.

\section{Hospital burden of RSV}

Details of all RSVHs were captured, including number of children admitted and total admissions, average length of stay (LOS), number of bed days and requirement for admission to an intensive care unit (ICU). RSVH rates (per 1000 children), 
Table 1 Diagnostic codes used to identify RSVHs and comorbidities

\begin{tabular}{|c|c|c|}
\hline Condition & ICD-10 code & ICD-10 code definition \\
\hline \multirow[t]{3}{*}{ RSV (definite) } & $\mathrm{J} 12.1$ & RSV pneumonia \\
\hline & $\mathrm{J} 20.5$ & Acute bronchitis due to RSV \\
\hline & $\mathrm{J} 21.0$ & Acute bronchiolitis due to RSV \\
\hline \multirow[t]{2}{*}{ RSV (probable) } & J20.9 & Acute bronchitis unspecified \\
\hline & $\mathrm{J} 21.9$ & Acute bronchiolitis unspecified \\
\hline \multirow[t]{5}{*}{ RSV (possible) } & $\mathrm{J} 12.8$ & Viral pneumonia unspecified \\
\hline & J12.9 & Bronchopneumonia unspecified \\
\hline & $\mathrm{J} 18.0$ & Lobar pneumonia unspecified \\
\hline & J18.9 & Pneumonia unspecified \\
\hline & $\mathrm{J} 22$ & Unspecified acute LRTI \\
\hline $\mathrm{CHD}$ or $\mathrm{PH}$ & Q20-Q26 & $\mathrm{CHD}$ or $\mathrm{PH}$ \\
\hline CLD or BPD & $\begin{array}{l}\text { P27.1, } \\
\text { Q30-Q34 }\end{array}$ & CLD or BPD \\
\hline Down syndrome & Q90 & Down syndrome \\
\hline Turner syndrome & Q96 & Turner syndrome \\
\hline Cystic fibrosis & E84 & Cystic fibrosis \\
\hline Cerebral palsy & G80 & Cerebral palsy \\
\hline $\begin{array}{l}\text { Neuromuscular } \\
\text { disorders }\end{array}$ & G71 & Neuromuscular disorders \\
\hline Other & D81.9, Q78.0 & $\begin{array}{l}\text { Combined immunodeficiency, unspecified; osteogenesis } \\
\text { imperfecta }\end{array}$ \\
\hline
\end{tabular}

$B P D$ bronchopulmonary dysplasia, $C H D$ congenital heart disease, $C L D$ congenital lung disease, $L R T I$ lower respiratory tract infection, $P H$ pulmonary hypertension, $R S V$ respiratory syncytial virus, RSVH: $R S V$ hospitalisation the seasonality of RSV burden (defined as October-March) and the incidence of RSVH in preterms $(\leq 36 \mathrm{wGA})$ and other recognised high-risk groups, including those with congenital heart disease (CHD)/pulmonary hypertension $(\mathrm{PH})$, congenital lung disease (CLD)/bronchopulmonary dysplasia (BPD), Down syndrome, cystic fibrosis, cerebral palsy and neuromuscular disorders (identified using ICD-10 codes; Table 1), were assessed.

\section{Statistical analysis}

Chi-squared tests and $t$ tests, as appropriate, were used to assess differences between groups. The Wilson method was used to calculate $95 \%$ confidence intervals for incidence rates. Analysis of RSVHs over time was via linear regression and ANOVA. RSVHs by month of birth were compared by chi-squared test. All analyses were performed using StatsDirect version 2.8.0, SPSS for Windows version 15.0, and Microsoft Excel.

\section{Results}

\section{Study population}

In total, 637,502 children were identified of whom 623,770 were included in the study (11,768 émigrés and 1964 non-
RSV-related deaths were excluded). Of the 623,770 children, $13,362(2.1 \%)$ had $\geq 1$ RSVH during the first 2 years of life. Children hospitalised for RSV were significantly more likely to be male $(56.5 \%$ vs. $51.0 \%)$, part of a multiple birth $(5.6 \%$ vs. $2.9 \%)$, delivered by emergency caesarean $(16.6 \%$ vs. 15.2\%), have a 5-min Apgar score of $<7$ (2.6\% vs. $1.3 \%$ ), and have a lower weight (median $3280 \mathrm{~g}$ vs. $3420 \mathrm{~g}$ ) and lower GA (median 39 vs. $40 \mathrm{wGA}$ ) at birth than those not hospitalised for RSV (all $p<0.0001$ ) (Table 2). The mothers of RSV-hospitalised children were younger (median age: 28 vs. 29 years), more often from the most deprived areas (SIMD 1 [most deprived] $30.7 \%$ vs. $25.5 \%$ ), were current smokers at pre-delivery assessment ( $34.0 \%$ vs. $23.8 \%$ ), and had $\geq 1$ prior pregnancy $(75.0 \%$ vs. $63.3 \%)$ than their counterparts (all $p<0.0001)$.

\section{Incidence and burden of RSVH}

The RSVH rate was $27.2 / 1000$ children $(16,946$ total RSVHs), equating to $1410 \mathrm{RSV}$ admissions per year over the study period. Readmissions for RSV occurred in $19.1 \%$ (2547) of children. The median age at first RSVH was 137 days (interquartile range [IQR] 62-264), with $84.3 \%$ of admissions occurring in the first year of life. Median inpatient LOS was 2 (IQR 1-4) days (mean 3.8 days, standard deviation [SD] 13.1). ICU admission was required for $4.3 \%$ (727) of 
Table 2 Demographics of children and mothers and incidence of RSVH

\begin{tabular}{|c|c|c|c|c|}
\hline \multicolumn{2}{|l|}{ Demographic factors } & RSVH children & Non-RSVH children & Incidence of RSVH $(95 \% \mathrm{CI})$ \\
\hline \multicolumn{2}{|l|}{ Number of children } & 13,362 & 610,408 & $2.1 \%(2.1-2.2 \%)$ \\
\hline \multicolumn{5}{|l|}{ Mothers } \\
\hline \multirow[t]{2}{*}{ Age at giving birth (years) } & Mean (SD) & $28.1(6.1)$ & $28.9(6.1)^{*}$ & - \\
\hline & Median [IQR] & $28[23-33]$ & 29 [24-33] & - \\
\hline \multirow[t]{5}{*}{ SIMD Quintile, $n(\%)$} & 1 -most deprived & $4090(30.7)$ & $154,969(25.5)^{*}$ & $2.6 \%(2.5-2.7 \%)$ \\
\hline & 2 & $2898(21.7)$ & $125,557(20.6)$ & $2.3 \%(2.2-2.3 \%)$ \\
\hline & 3 & $2319(17.4)$ & $112,694(18.5)$ & $2.0 \%(1.9-2.1 \%)$ \\
\hline & 4 & $2073(15.6)$ & $110,366(18.1)$ & $1.8 \%(1.8-1.9 \%)$ \\
\hline & 5-least deprived & 1947 (14.6) & $105,278(17.3)$ & $1.8 \%(1.7-1.9 \%)$ \\
\hline \multirow[t]{3}{*}{ Smoking history at pre-delivery assessment, $n(\%)$} & Current & $4095(34.0)$ & $131,157(23.8)^{*}$ & $3.0 \%(2.9-3.1 \%)$ \\
\hline & Former & $1141(9.5)$ & $58,859(10.7)$ & $1.9 \%(1.8-2.0 \%)$ \\
\hline & Never & $6805(56.5)$ & $360,410(65.5)$ & $1.9 \%(1.8-1.9 \%)$ \\
\hline \multirow[t]{3}{*}{ Previous pregnancies, $n(\%)$} & 0 & $3336(25.0)$ & $223,800(36.7)$ & $1.5 \%(1.4-1.5 \%)$ \\
\hline & 1 & $4346(32.5)$ & $188,201(30.8)^{\dagger}$ & $2.3 \%(2.2-2.3 \%)$ \\
\hline & $2+$ & $5680(42.5)$ & $198,404(32.5)^{\dagger}$ & $2.8 \%(2.7-2.9 \%)$ \\
\hline \multicolumn{5}{|l|}{ Children and births } \\
\hline Gender, $n(\%)$ & Male & $7554(56.5)$ & $311,535(51.0)^{*}$ & $2.4 \%(2.3-2.4 \%)$ \\
\hline \multirow[t]{2}{*}{ Multiple births, $n(\%)$} & Singleton & $12,616(94.4)$ & $592,912(97.1)$ & $2.1 \%(2.0-2.1 \%)$ \\
\hline & Multiple & $744(5.6)$ & $17,469(2.9)^{*}$ & $4.1 \%(3.8-4.4 \%)$ \\
\hline Emergency caesarean, $n(\%)$ & Percentage requiring & $2224(16.6)$ & $92,738(15.2)^{*}$ & $2.3 \%(2.2-2.4 \%)$ \\
\hline \multirow[t]{2}{*}{ Apgar score, $n(\%)$} & $<7$ & $347(2.6)$ & $8022(1.3)^{*}$ & $4.1 \%(3.7-4.6 \%)$ \\
\hline & $\geq 7$ & $12,795(97.4)$ & $593,129(98.7)$ & $2.1 \%(2.1-2.1 \%)$ \\
\hline \multirow[t]{2}{*}{ Gestational age at birth (weeks) } & Mean (SD) & $38.2(2.9)$ & $39.3(2.1)^{*}$ & - \\
\hline & Median [IQR] & $39[38-40]$ & $40[39-41]$ & - \\
\hline \multirow[t]{2}{*}{ Birthweight (g) } & Mean (SD) & $3177(761)$ & $3395(586) *$ & - \\
\hline & Median [IQR] & $\begin{array}{l}3280 \\
{[2810-3680]}\end{array}$ & $\begin{array}{l}3420 \\
{[3070-3770]}\end{array}$ & - \\
\hline
\end{tabular}

$C I$ confidence interval, IQR: interquartile range, $R S V H$ respiratory syncytial virus hospitalisation, $S D$ standard deviation, SIMD Scottish Index of Multiple Deprivation

$* p<0.0001$ vs. $\mathrm{RSVH}$ group ${ }^{\dagger} p<0.0001$ for combined $\geq 1$ pregnancies vs. RSVH group

cases for a median of 5 (IQR 2-8) days (mean 7.0 days, SD 10.0). RSVHs accounted for $6.9 \%(5089 / 73,525)$ of ICU bed days and $6.2 \%(64,395 / 1,033,121)$ of overall bed days $(5370$ per year) for children $\leq 2$ years during the study period. The majority $(91.7 \% ; 15,538)$ of RSVHs occurred between October and March, representing 8.5\% $(14,243 / 168,205)$ of all admissions in children $\leq 2$ years during this time period. During the peak months of December and January, RSV accounted for $14.2 \%(8470 / 59,535)$ of all such admissions. RSVH rates varied across years and RSV seasons, ranging from $1.7 \%$ of children born in $2001(840 / 48,775)$ to $2.5 \%$ $(1258 / 50,586)$ in 2000 , with no significant $(p=0.20)$ change in incidence seen over the study period (Fig. 1). The RSVH rate also varied by month of birth, with a rate higher than the study mean $(2.1 \%)$ observed between August and December (range 2.2-3.4\%; Fig. 2). The RSVH rate was highest for children born in October (3.2\%) and November (3.4\%), when it was over 2-fold higher than the rate for children born in
March (month with lowest RSVH rate: $1.4 \%$; both $p<0.001$ vs. March).

\section{RSVH in children born prematurely and those with comorbidities}

Preterms $(\leq 36 \mathrm{wGA})$ were at a significantly increased risk of RSVH compared to children born at term $(5.2 \%$ vs. $1.9 \%$, respectively; $p<0.0001$ ) (Table 3 ). The risk of RSVH decreased with increasing GA, but remained significantly higher versus term for all groups analysed: $<29$ wGA $12.8 \%$; 29-32 wGA $8.2 \%$; $33-35$ wGA $4.6 \%$ (all $p<0.0001$ ). The RSVH rate was significantly higher in children from multiple births than singletons ( 40.6 vs. $20.8 / 1000$, respectively; $p<0.0001$ ), with this being most pronounced in preterm $(\leq 35 \mathrm{wGA})$ than term children (64.8 vs. $23.2 / 1000 ; p<0.0001)$.

Relevant comorbidities were diagnosed in $7.1 \%$ (951/ 13,362) of children hospitalised for RSV compared to $1.2 \%$ 


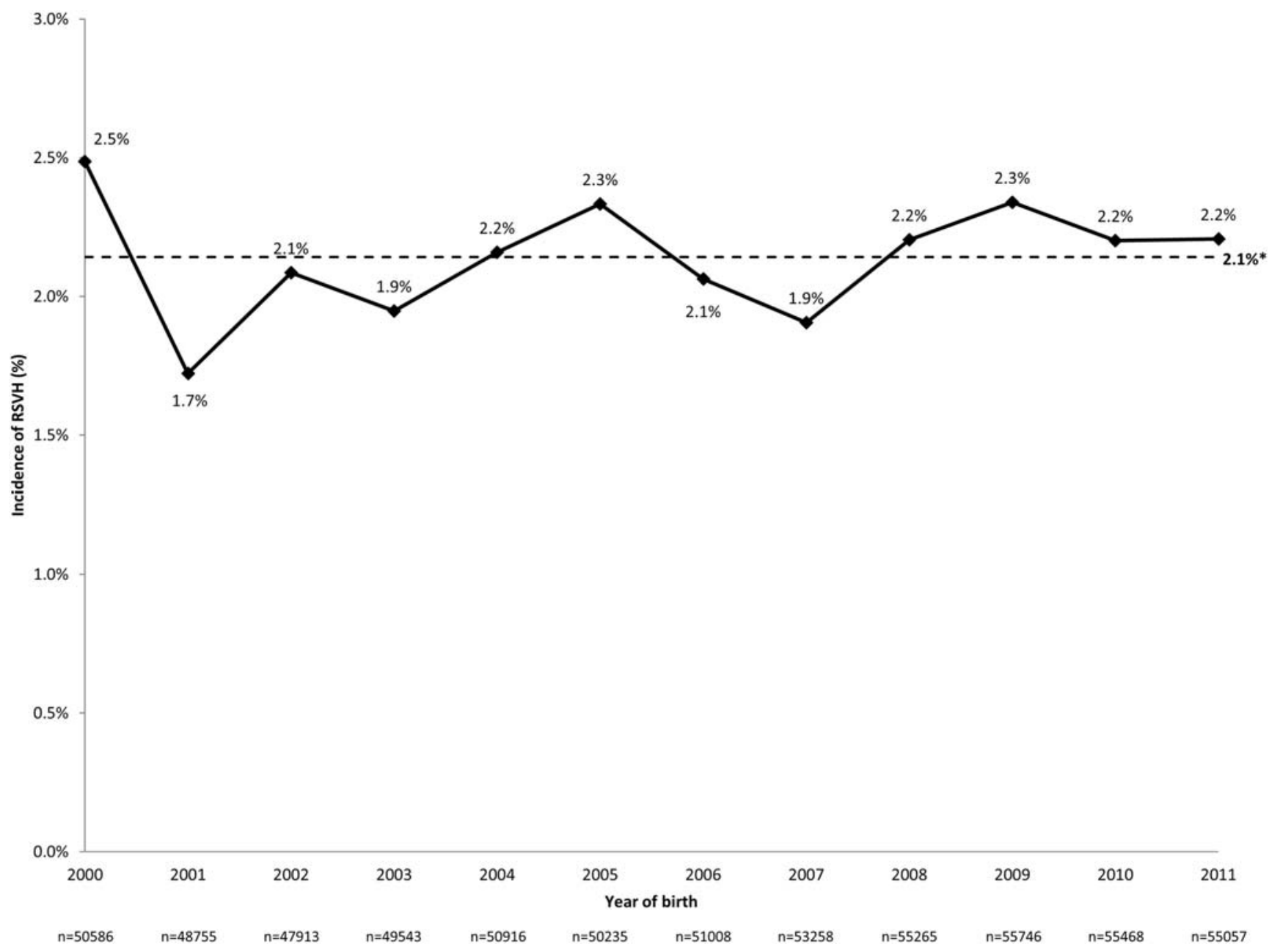

Fig. 1 Incidence of RSVHs by year of birth. *Weighted mean; significance of non-zero linear relationship/trend over time: ANOVA, $p=0.20$

(7542/610,408; $p<0.0001)$ of those not RSV-hospitalised (Table 3). An increased risk of RSVH was seen in children with CHD/PH (10.5\%), CLD/BPD (11.2\%), Down syndrome (14.8\%), cerebral palsy (15.5\%), cystic fibrosis (12.6\%) and neuromuscular disorders $(17.0 \%)$, compared with children without a comorbidity $(2.0 \%$; all $p<0.0001)$.

\section{Maximal burden of RSVH}

There were 10,404 children with a 'probable' RSVH and 4977 with a 'possible' RSVH identified. Combining the 'definite', 'probable' and 'possible' groups gave a maximum of 35,212 admissions for RSV (rate of 56.5/1000 children). These admissions accounted for $10.3 \%(106,400 / 1,033,121)$ of overall bed days for children $\leq 2$ years during the study period, and $23.9 \%(14,257 / 59,535)$ of all admissions in December and January. A similar pattern of seasonality was shown by the 'definite' and 'probable' groups, with $91.7 \%(15,538 / 16,946)$ and $79.8 \%(10,174 / 12,744)$ of hospitalisations occurring during the RSV season; such seasonality was less apparent for the 'possible' group (59.6\%; 3290/5522) (Fig. 3). By removing excess admissions throughout the year, it was calculated that $23.7 \%$ of 'probable' and $64.2 \%$ of 'possible' hospitalisations are likely not be RSV-related. Assuming this to be the case, the maximal RSVH rate was estimated to be 45.9/1000.

\section{Discussion}

This 12 -year study of $>600,000$ children provides comprehensive evidence of the substantial clinical burden of RSV in children $\leq 2$ years of age in Scotland. RSVHs accounted for $6.2 \%$ of all inpatient bed days and $6.9 \%$ of all ICU bed days in these children. During the peak months of the RSV season, December and January, this increased to approximately one in seven $(14.2 \%)$ of all bed days. In total, this represented over 1400 hospitalisations and nearly 5500 bed days each year. The overall RSVH rate was 27.2/1000 children over the first 2 years of life, with $2.1 \%$ of children being hospitalised $\geq 1$ times.

A number of studies and surveillance data from England indicate a rising incidence of RSVH over the past 15 years 


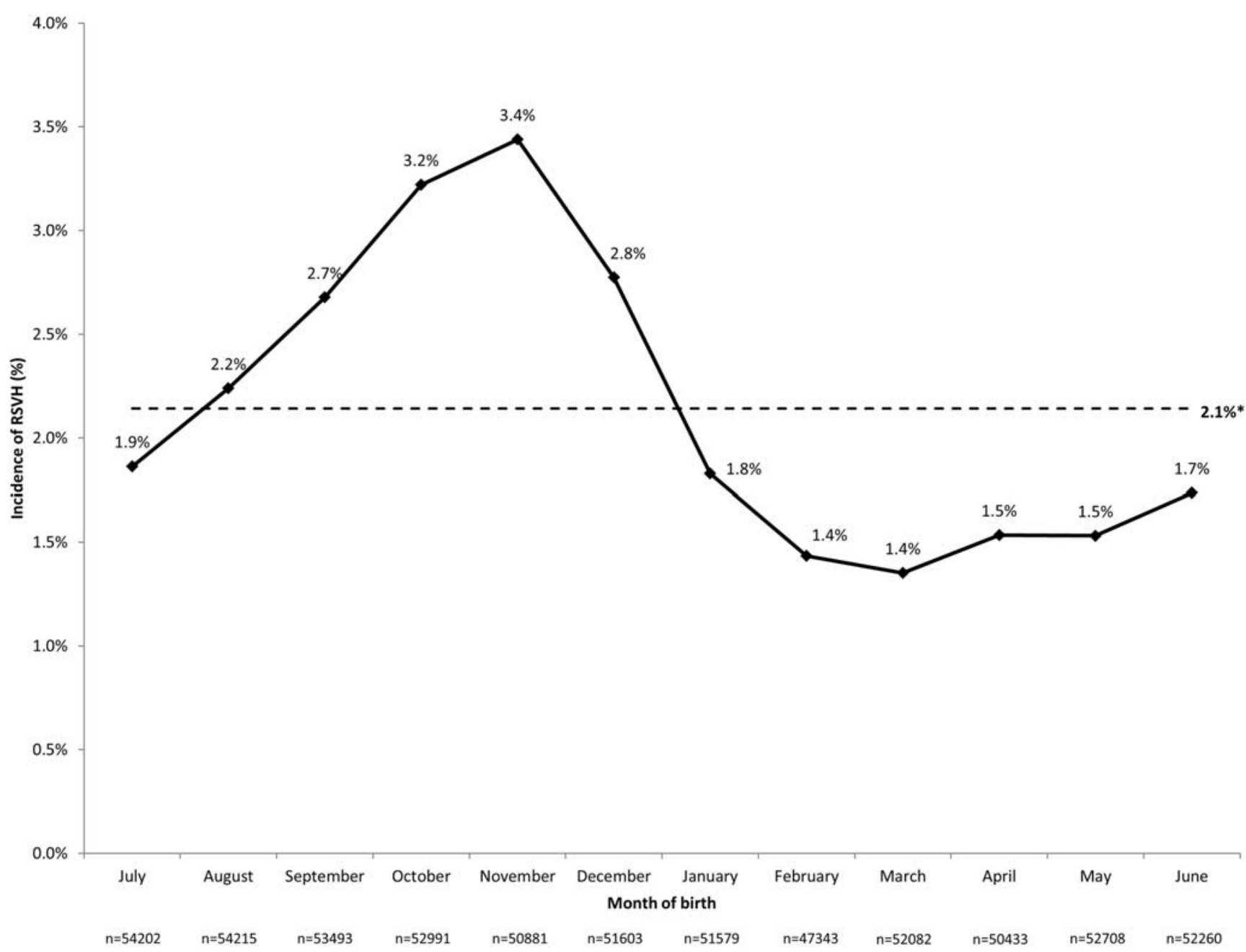

Fig. 2 RSVH incidence by month of birth. *Weighted mean

[5, 10-12], with one study (1995-2009) reporting relatively stable rates [13]. An analysis of 468,138 bronchiolitis episodes (1979-2011) estimated a hospitalisation rate of 46.1/ 1000 infants aged $<1$ year in 2011, with the incidence increasing by $1.8 \%$ per year between 2004 and 2011 [10]. Another recent study (2007-2012) estimated a RSVH rate of 35.1/1000 infants < 1 year, based on 121,968 respiratory admissions, with a general increase in RSVHs over the study period [5]. The authors also noted that by restricting the definition of RSVH to those with a primary diagnosis of upper respiratory tract infection and LRTI, they might have underestimated the true burden of disease [5]. This apparent increase in RSVHs perhaps reflects, in part, rising rates of emergency admissions in children in general within the UK [11], increasing use of pulse oximetry, leading to more infants with hypoxaemia being identified and admitted than on purely clinical grounds [14], and more widespread availability of rapid antigen detection tests for RSV at point-ofcare. Our study, in contrast, observed a relatively stable rate of RSVH over time in Scotland. This may relate to RSV testing being routine in Scotland over the study period (email communication between Scottish paediatric inpatient units and Jonathan Coutts, December 2018).

Differing methodologies, data sources, populations and RSVH definitions complicate comparisons between studies. In general, earlier studies (1990s to early 2000s) have tended to report lower RSVH rates than those conducted in the last decade $[5,6,13,15-18]$. One study of 15,116 children < 2 years reported a RSVH rate of $16.3 / 1000$ between 1996 and 1999, based on a positive immunofluorescence test [6]. This is just over half the rate found in our study (27.2/1000), albeit this rate was calculated over 2 years so it is not directly comparable. The average LOS (ours: median 2 days vs. median 2 days [6]) and admission to ICU (4.3\% vs. $2.7 \%$ [6]) in both studies, however, were broadly similar.

Our study provides further evidence for several high-risk groups and known risk factors for RSVH, including birth in proximity to the RSV season, maternal smoking, low social class/deprivation, male sex, siblings in the household, and multiple births [19-21]. Children born prematurely were found to be at increased risk of RSVH, including those born moderate-late preterm (33-35 wGA), where the incidence 
Table 3 Incidence of RSVH in preterms and other high-risk groups

\begin{tabular}{|c|c|c|c|c|}
\hline & & $\begin{array}{l}\text { RSVH } \\
\text { children }\end{array}$ & $\begin{array}{l}\text { Non-RSVH } \\
\text { children }\end{array}$ & $\begin{array}{l}\text { Incidence of RSVH } \\
(95 \% \mathrm{CI})\end{array}$ \\
\hline \multirow{7}{*}{$\begin{array}{l}\text { Gestational age at } \\
\text { birth }\end{array}$} & $<29$ weeks & 277 & 1891 & $12.8 \% *(11.4-14.3 \%)$ \\
\hline & $<32$ weeks & 839 & 5453 & $13.3 \% *(12.5-14.2 \%)$ \\
\hline & 29-32 weeks & 562 & 6329 & $8.2 \% *(7.5-8.8 \%)$ \\
\hline & $<36$ weeks & 1710 & 26,279 & $6.1 \% *(5.8-6.4 \%)$ \\
\hline & $\leq 36$ weeks & 2320 & 42,319 & $5.2 \% *(5.0-5.4 \%)$ \\
\hline & 33-35 weeks & 871 & 18,059 & $4.6 \% *(4.3-4.9 \%)$ \\
\hline & $>36$ weeks & 11,023 & 567,711 & $1.9 \%(1.9-1.9 \%)$ \\
\hline \multirow[t]{8}{*}{ Comorbidities } & $\mathrm{CHD}$ and $\mathrm{PH}$ & 534 & 4576 & $10.5 \%+(9.6-11.3 \%)$ \\
\hline & CLD and BPD & 228 & 1803 & $11.2 \%+(9.9-12.7 \%)$ \\
\hline & Down syndrome & 87 & 500 & $14.8 \%^{\star}(12.0-18.0 \%)$ \\
\hline & Turner syndrome & 1 & 42 & $2.3 \%(0.1-12.3 \%)$ \\
\hline & Cystic fibrosis & 30 & 209 & $12.6 \%+(8.6-17.4 \%)$ \\
\hline & Cerebral palsy & 61 & 332 & $15.5 \%+(12.1-19.5 \%)$ \\
\hline & $\begin{array}{l}\text { Neuromuscular } \\
\text { disorders }\end{array}$ & 8 & 39 & $17.0 \% \%^{\ddagger}(7.6-30.8 \%)$ \\
\hline & Other $^{\dagger}$ & 2 & 41 & $4.7 \%(0.6-15.8 \%)$ \\
\hline No comorbidities & & 12,411 & 602,866 & $2.0 \%(2.0-2.1 \%)$ \\
\hline
\end{tabular}

$B P D$ bronchopulmonary dysplasia, $C H D$ congenital heart disease, $C I$ confidence interval, $C L D$ congenital lung disease, $P H$ pulmonary hypertension, $R S V H$ respiratory syncytial virus hospitalisation

${ }^{*} p<0.0001$ vs. term (> 36 weeks’ gestational age); ${ }^{\ddagger} p<0.0001$ vs. no comorbidities; ${ }^{\dagger}$ congenital immunodeficiency disorders and osteogenesis imperfecta was more than double that in term children (4.6\% vs. $1.9 \%$, respectively; $p<0.0001)$. These data support the case for preventive strategies against severe RSV infection in preterm infants [22-24]. In addition to established high-risk comorbidities, such as CLD/BPD and CHD, our study provides valuable new data on the increased risk of RSVH in children with Down syndrome (RSVH incidence: 14.8\%), cystic fibrosis (12.6\%), cerebral palsy $(15.5 \%)$, and neuromuscular disorders (17.0\%), where published data are more scarce [25].

The primary analysis in this paper focussed on the RSV diagnoses J12.1, J20.5 and J21.0 and, with RSV testing routine in almost all paediatric inpatient units in Scotland, this is likely to provide a robust estimate of the burden of RSVH in Scotland. However, it is acknowledged that this approach has certain limitations in that it relies on coding precision and
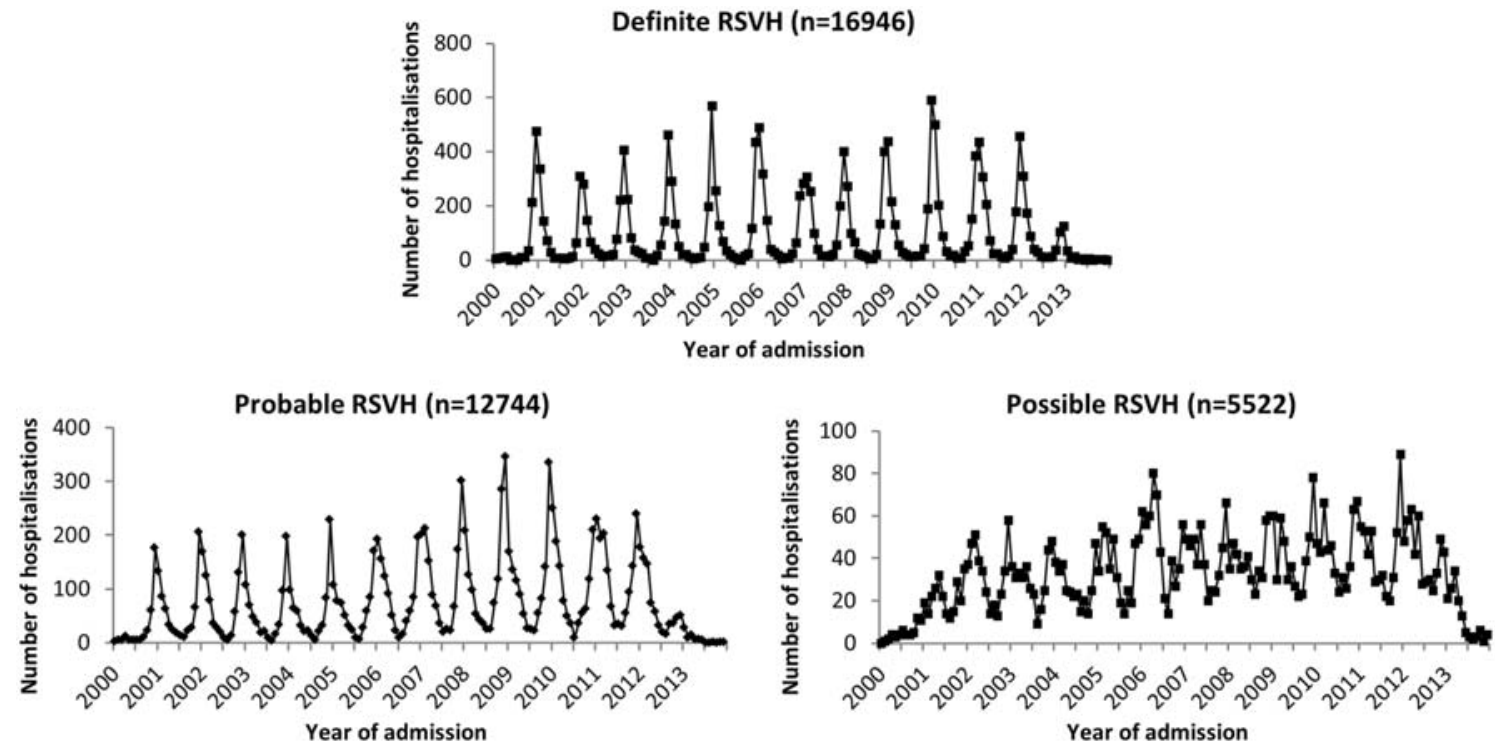

Fig. 3 RSVH over time and by certainty of diagnosis. See Table 1 for full group definitions 
might, therefore, underestimate the true burden of RSVH. By including additional ICD-10 codes for 'probable' and 'possible' RSV cases, as has been done in other studies [2, 5], it was estimated that the maximal rate of RSVH was 45.9/1000. Another limitation is that there is no method to identify through the ISD databases those children that received palivizumab prophylaxis, although during the time period palivizumab use was restricted on a case-by-case basis to infants $<12$ months with extreme prematurity, acyanotic CHD, congenital or acquired significant lung diseases, and immunodeficiency [26]; hence, the impact on overall rates would have been minimal.

This study, which covered all live births from 2000 to 2011, provides a reliable estimate of the significant and rising burden of RSVH in young children ( $<2$ years) in Scotland. These data can aid the planning and delivery of preventive strategies and care and highlight the need for the development of an effective vaccine.

Acknowledgements Matthew Freddi of Strategen provided medical writing and editing services in the development of this publication. David Bailey of ISD Scotland worked as a data analyst on this study. AbbVie provided funding for this work.

Authors' contribution All authors contributed to the study conception and design. Material preparation, data collection and analysis were performed by all authors. The first draft of the manuscript was written by SB and BRG and all authors commented on this and subsequent versions of the manuscript. All authors read and approved the final manuscript.

Funding Financial support for this study was provided by AbbVie.

\section{Compliance with ethical standards}

Conflict of interest JC and RT have received research funding and/or compensation as advisor/lecturer from AbbVie. SB, BRG and JF are employees of Strategen. Strategen has received consultancy and research fees from AbbVie for work on this and other projects. CM is an employee of ISD Scotland. ISD Scotland has received research fees from AbbVie for data analysis work on this project. EG is an employee of AbbVie and holds stock in AbbVie.

Ethical approval The UK National Research Ethic Service confirmed that ethical approval was not required and the ISD Privacy Advisory Committee gave their approval for the study. All data were accessed and analysed using the ISD 'Safe Haven' system to ensure anonymity, confidentiality, and security.

Open Access This article is licensed under a Creative Commons Attribution 4.0 International License, which permits use, sharing, adaptation, distribution and reproduction in any medium or format, as long as you give appropriate credit to the original author(s) and the source, provide a link to the Creative Commons licence, and indicate if changes were made. The images or other third party material in this article are included in the article's Creative Commons licence, unless indicated otherwise in a credit line to the material. If material is not included in the article's Creative Commons licence and your intended use is not permitted by statutory regulation or exceeds the permitted use, you will need to obtain permission directly from the copyright holder. To view a copy of this licence, visit http://creativecommons.org/licenses/by/4.0/.

\section{References}

1. Shi T, McAllister DA, O'Brien KL, Simoes EAF, Madhi SA, Gessner BD, Polack FP, Balsells E, Acacio S, Aguayo C et al (2017) Global, regional, and national disease burden estimates of acute lower respiratory infections due to respiratory syncytial virus in young children in 2015: a systematic review and modelling study. Lancet 390:946-958. https://doi.org/10.1016/S01406736(17)30938-8

2. Gil-Prieto R, Gonzalez-Escalada A, Marín-García P, Gallardo-Pino C, Gil-de-Miguel A (2015) Respiratory syncytial virus bronchiolitis in children up to 5 years of age in spain: epidemiology and comorbidities: an observational study. Medicine (Baltimore) 94:e831. https://doi.org/10.1097/MD.0000000000000831

3. Helfrich AM, Nylund CM, Eberly MD, Eide MB, Stagliano DR (2015) Healthy Late-preterm infants born 33-36 +6 weeks gestational age have higher risk for respiratory syncytial virus hospitalization. Early Hum Dev 91:541-546. https://doi.org/10.1016/j. earlhumdev.2015.06.009

4. McLaurin KK, Farr AM, Wade SW, Diakun DR, Stewart DL (2016) Respiratory syncytial virus hospitalization outcomes and costs of full-term and preterm infants. J Perinatol 36:990-996. https://doi.org/10.1038/jp.2016.113

5. Reeves RM, Hardelid P, Gilbert R, Warburton F, Ellis J, Pebody RG (2017) Estimating the burden of respiratory syncytial virus (RSV) on respiratory hospital admissions in children less than five years of age in England, 2007-2012. Influenza Other Respir Viruses 11: 122-129. https://doi.org/10.1111/irv. 12443

6. Deshpande SA, Northern V (2003) The clinical and health economic burden of respiratory syncytial virus disease among children under 2 years of age in a defined geographical area. Arch Dis Child 88:1065-1069. https://doi.org/10.1136/adc.88.12.1065

7. Broughton S, Roberts A, Fox G, Pollina E, Zuckerman M, Chaudhry S, Greenough A (2005) Prospective study of healthcare utilisation and respiratory morbidity due to RSV infection in prematurely born infants. Thorax 60:1039-1044. https://doi.org/10. 1136/thx.2004.037853

8. Information Services Division (ISD) Scotland. About ISD. http:// www.isdscotland.org/ Accessed April 2018.

9. Scottish Government (2016) Scottish Index of multiple deprivation: background and methodology. Scottish Government. http://www. gov.scot/Topics/Statistics/SIMD/BackgroundMethodology Accessed April 2018.

10. Green CA, Yeates D, Goldacre A, Sande C, Parslow RC, McShane P, Pollard AJ, Goldacre MJ (2016) Admission to hospital for bronchiolitis in England: trends over five decades, geographical variation and association with perinatal characteristics and subsequent asthma. Arch Dis Child 101:140-146. https://doi.org/10.1136/ archdischild-2015-308723

11. Gill PJ, Goldacre MJ, Mant D, Heneghan C, Thomson A, Seagroatt V, Harnden A (2013) Increase in emergency admissions to hospital for children aged under 15 in England, 1999-2010: national database analysis. Arch Dis Child 98:328-334. https://doi.org/10.1136/ archdischild-2012-302383

12. Six major respiratory viruses reported from PHE and NHS laboratories (SGSS) in England and Wales between week 01 of 2007 and week 10 of 2018. Published 24 July 2014; updated 22 March 2018. Available at: https://assets.publishing.service.gov.uk/government/ uploads/system/uploads/attachment_data/file/693127/six_ pathogens___Jan2007-Mar2018.pdf Accessed June 2018.

13. Taylor S, Taylor RJ, Lustig RL, Schuck-Paim C, Haguinet F, Webb DJ, Logie J, Matias G, Fleming DM (2016) Modelling estimates of the burden of respiratory syncytial virus infection in children in the UK. BMJ Open 6:e009337. https://doi.org/10.1136/bmjopen-2015009337 
14. Langley R, Cunningham S (2017) How Should oxygen supplementation be guided by pulse oximetry in children: do we know the level? Front Pediatr 4:138. https://doi.org/10.3389/fped.2016. 00138

15. Clark SJ, Beresford MW, Subhedar NV, Shaw NJ (2000) Respiratory syncytial virus infection in high risk infants and the potential impact of prophylaxis in a United Kingdom cohort. Arch Dis Child 83:313-316. https://doi.org/10.1136/adc.83.4.313

16. Murray J, Bottle A, Sharland M, Modi N, Aylin P, Majeed A, Saxena S, Medicines for Neonates Investigator Group (2014) Risk factors for hospital admission with RSV bronchiolitis in England: a population-based birth cohort study. PLoS One 26: e89186. https://doi.org/10.1371/journal.pone.0089186

17. Müller-Pebody B, Edmunds WJ, Zambon MC, Gay NJ, Crowcroft NS (2002) Contribution of RSV to bronchiolitis and pneumoniaassociated hospitalizations in English children, April 1995-March 1998. Epidemiol Infect 129:99-106. https://doi.org/10.1017/ S095026880200729X

18. Ajayi-Obe EK, Coen PG, Handa R, Hawrami K, Aitken C, McIntosh ED, Booy R (2008) Influenza A and respiratory syncytial virus hospital burden in young children in East London. Epidemiol Infect 136:1046-1058. https://doi.org/10.1017/ S0950268807009557

19. Bont L, Checchia PA, Fauroux B, Figueras-Aloy J, Manzoni P, Paes B, Simões EA, Carbonell-Estrany X (2016) Defining the epidemiology and burden of severe respiratory syncytial virus infection among infants and children in western countries. Infect Dis Ther 5:271-298. https://doi.org/10.1007/s40121-016-0123-0

20. Simoes EA (2003) Environmental and demographic risk factors for respiratory syncytial virus lower respiratory tract disease. J Pediatr 143:S118-S126. https://doi.org/10.1067/S0022-3476(03)00511-0
21. Lloyd PC, May L, Hoffman D, Riegelman R, Simonsen L (2014) The effect of birth month on the risk of respiratory syncytial virus hospitalization in the first year of life in the United States. Pediatr Infect Dis J 33:e135-e140. https://doi.org/10.1097/INF. 0000000000000250

22. Paes B (2018) Respiratory syncytial virus in otherwise healthy prematurely born infants: a forgotten majority. Am J Perinatol 35:541544. https://doi.org/10.1055/s-0038-1637762

23. Figueras-Aloy J, Manzoni P, Paes B, Simões EA, Bont L, Checchia PA, Fauroux B, Carbonell-Estrany X (2016) Defining the risk and associated morbidity and mortality of severe respiratory syncytial virus infection among preterm infants without chronic lung disease or congenital heart disease. Infect Dis Ther 5:417-452. https://doi. org/10.1007/s40121-016-0130-1

24. Blanken MO, Paes B, Anderson EJ, Lanari M, Sheridan-Pereira M, Buchan S, Fullarton JR, Grubb E, Notario G, Rodgers-Gray BS, Carbonell-Estrany X (2018) Risk scoring tool to predict respiratory syncytial virus hospitalisation in premature infants. Pediatr Pulmonol 53(5):605-612. https://doi.org/10.1002/ppul.23960

25. Manzoni P, Figueras-Aloy J, Simões EAF, Checchia PA, Fauroux B, Bont L, Paes B, Carbonell-Estrany X (2017) Defining the Incidence and associated morbidity and mortality of severe respiratory syncytial virus infection among children with chronic diseases. Infect Dis Ther 6:383-411. https://doi.org/10.1007/s40121-0170160-3

26. Scottish Intercollegiate Guidelines Network (SIGN) (2006) 91: Bronchiolitis in children - a national clinical guideline.

Publisher's note Springer Nature remains neutral with regard to jurisdictional claims in published maps and institutional affiliations. 